\title{
PENGARUH KONVERGENSI IFRS TERHADAP PERSISTENSI LABA: STUDI PADA PERUSAHAAN YANG TERDAFTAR DI BURSA EFEK INDONESIA PERIODE 2012-2015
}

\author{
Vania Adi \\ Universitas Surabaya \\ Dr. Yie Ke Feliana, S.E., M.Com., Ak., CPA., CFP., CA. \\ Universitas Surabaya \\ yiekefeliana@staff.ubaya.ac.id
}

\begin{abstract}
This research aims to test whether the more convergent IFRS in Indonesia can make company's earning more persistence or not, also this research aim to test can the operating income this year can predict the net income in next year more rather than non-operating income.

This research uses quantitative approach with multiple regression analysis. Researcher use companies listed in Indonesia Stock Exchange within 2012 - 2015 period as the sample. There are 304 companies used in this research.

The results show that the more convergent IFRS in Indonesia can make company's earning more persistence even the coefficient value fluctuates, so the net income in current year can be used to predict the net income in next year. Meanwhile, operating income proved can predict net income in next year rather than non-operating income even the ability to predict was decreased in 2015.
\end{abstract}

Keywords: IFRS, earnings persistent, operating income

\section{PENDAHULUAN}

Pentingnya informasi dalam laporan keuangan mengakibatkan laba yang dilaporkan perusahaan harus memiliki kualitas yang andal karena kualitas informasi akuntansi sering ditentukan oleh kualitas laba yang dilaporkan (Schipper dan Vincent, 2003). Sementara itu, laba perusahaan sangat dipengaruhi oleh standar akuntansi yang digunakan untuk pelaporan. Oleh karena itu, dibutuhkan sebuah aturan atau standar yang dapat meningkatkan kualitas pengungkapan dan pelaporan keuangan yang mampu menghasilkan laba perusahaan yang berkualitas. Berdasarkan sifat runtun waktu, laba yang berkualitas dapat ditentukan dengan tiga cara, salah satunya adalah melalui persistensi (Schipper dan Vincent, 2003). Dengan dasar persistensi, laba dapat dikatakan berkualitas apabila laba perusahaan berkelanjutan, lebih bersifat permanen, dan tidak transitory. Laba yang persisten juga akan mempengaruhi keputusan investasi dari investor. Karena, laba yang semakin persisten menunjukkan laba yang semakin informatif (Tucker dan Zarowin, 2006). 
Di Indonesia, perusahaan menggunakan acuan standar untuk pelaporan keuangan, yaitu Standar Akuntansi Keuangan (SAK). SAK awalnya mengacu pada US GAAP (Generally Accepeted Accounting Standard). Munculnya IFRS (International Financial Reporting Standard) yang diterbitkan oleh IASB (International Accounting Standard Board) dan berlaku secara internasional, menyebabkan perlunya harmonisasi standar laporan keuangan antara SAK dengan IFRS. IAI (Ikatan Akuntansi Indonesia) memilih untuk melakukan konvergensi dari PSAK berbasis GAAP ke IFRS secara perlahan (gradually) mulai tahun 2008. IFRS dibentuk dengan tujuan untuk dasar guna standar akuntansi pada masa mendatang yang berbasis prinsip, konsisten secara internal dan diterima secara internasional. Sehingga, IFRS berdasar prinsip-prinsip saja, berbeda dengan GAAP yang berdasar aturan. Konvergensi IFRS diharapkan dapat memfasilitasi pertumbuhan di pasar ekuitas Indonesia dengan menyediakan laporan yang berkualitas tinggi sehingga dapat melayani kebutuhan investor dan perusahaan. Seperti telah dijabarkan sebelumnya, laba yang persisten dapat menunjukkan kinerja perusahaan. dan laba perusahaan tergantung pada standar pelaporan keuangan yang digunakan.

Penelitian Doukakis (2010) pada negara Yunani, penerapan IFRS dalam pelaporan keuangan tidak meningkatkan persistensi laba. Penelitian Shobriati dan Siregar (2016) pada negara emerging market, seperti Indonesia, Malaysia, dan Filipina, tingkat adopsi IFRS tidak berpengaruh terhadap persistensi laba di masa yang akan datang. Sedangkan penelitian yang dilakukan Pahlevi (2014) memberikan hasil yang positif antara penerapan IFRS dengan persistensi laba pada perusahaan yang bergerak di bidang perbankan. Sejalan dengan penelitian Pahlevi, studi empiris yang dilakukan oleh Prastika, Yohani dan Kurniawati (2014) menyatakan bahwa terdapat perbedaan yang signifikan antara persistensi laba sebelum dan sesudah diterapkannya IFRS. Penerapan IFRS membuat laba menjadi semakin persisten. Penelitian Doukakis dan penelitian Pahlevi memberikan hasil yang bertolak belakang satu dengan yang lain. Oleh karena itu, peneliti hendak mengetahui apakah dengan semakin konvergen IFRS maka semakin persisten laba badan usaha dan apakah operating income tahun berjalan dapat lebih memprediksi net income di tahun berikutnya. 


\section{TELAAH TEORETIS}

\section{Pengertian Laba}

Setiap perusahaan membutuhkan dana untuk tetap bisa beroperasi. Di awal usaha, dana untuk beroperasi bisa didapat melalui modal dari pemilik dan/atau dana pinjaman. Setelah beroperasi, perusahaan tentunya berharap akan memperoleh hasil dari aktivitas operasinya, berupa keuntungan atau yang biasa disebut dengan laba. Menurut Horngren (1997), bahwa laba merupakan kelebihan total pendapatan dibandingkan total bebannya. Sedangkan menurut Suwardjono (2008:464), laba dimaknai sebagai imbalan atas upaya perusahaan menghasilkan barang dan jasa. Ini berarti laba merupakan kelebihan pendapatan di atas biaya (biaya total yang melekat dalam kegiatan produksi dan penyerahan barang/jasa).

\section{Persistensi Laba}

Menurut Penman (2003), laba dapat dikelompokkan menjadi dua, yaitu sustainable NI (NI persistence atau core NI) dan unusual NI atau transitory NI. Persistensi laba merupakan laba yang mempunyai kemampuan sebagai indikator laba periode mendatang yang dihasilkan oleh perusahaan secara berulang-ulang dalam jangka panjang. Sementara itu, unusual NI atau transitory NI merupakan laba yang tidak dapat dihasilkan secara berulang-ulang sehingga tidak dapat digunakan sebagai indikator laba periode mendatang. Ketika para pengguna laporan keuangan, terutama pihak investor, memandang laba perusahaan sustainable, maka expected dividend yield tumbuh secara stasioner, Persistensi laba memfokuskan pada koefisien dari regresi laba sekarang terhadap laba mendatang. Hubungan tersebut dapat dilihat dari koefisien slope regresi antara laba sekarang dengan laba di masa mendatang. Semakin tinggi koefisien regresinya, maka peristensi laba yang dihasilkan semakin tinggi. Jika mendekati 0, persistensinya semakin rendah (Fama dan French, 2002).

Amir, Einhorn dan Kama (2012) menyatakan bahwa komponen laba yang bersifat sementara dapat dilihat pada komposisi pembentuk laba pada laporan laba rugi. Salah satu contohnya adalah penghentian operasi perusahaan (discontinued operation). Menurut Sunarto (2008), persistensi laba didefinisikan sebagai laba yang dapat digunakan sebagai pengukur laba itu sendiri. Artinya, laba saat ini dapat digunakan sebagai indikator laba periode mendatang (future earnings). Dengan kata lain, laba yang mencerminkan core earnings 
sehingga karena mampu menjelaskan core dan mampu membedakan maka akan dinyatakan persisten.

\section{International Financial Reporting Standard}

Menurut Handayaningsih (2015), secara umum terdapat 4 hal pokok yang diatur dalam standar akuntansi. Pertama, berkaitan dengan definisi elemen laporan keuangan atau informasi lain yang berkaitan. Definisi digunakan untuk menentukan apakah transaksi tertentu harus dicatat dan dikelompokkan ke dalam akun aset, liabilitas, ekuitas, pendapatan dan biaya. Kedua, pengukuran dan penilaian. Hal kedua ini digunakan untuk menentukan nilai dari suatu elemen laporan keuangan baik pada saat terjadinya transaksi keuangan maupun pada saat penyajian laporan keuangan. Hal ketiga, mengenai pengakuan yang merupakan kriteria untuk mengakui elemen laporan keuangan sehingga elemen tersebut dapat disajikan dalam laporan keuangan. Dan hal pokok keempat adalah penyajian dan pengungkapan laporan keuangan yang digunakan untuk menentukan jenis informasi dan bagaimana informasi tersebut disajikan dan diungkapkan dalam laporan keuangan.

Pada 2010, Indonesia menganjurkan perusahaan yang memenuhi syarat untuk mengadopsi IFRS. Dan pada 2012, Dewan Pengurus Nasional IAI bersama dengan Dewan Konsultatif SAK dan DSAK merencanakan akan menerapkan standar akuntansi yang mendekati konvergensi penuh kepada IFRS (dalam Nurhayati dan Maryono, 2013). Konvergensi IFRS fase 1 telah dilakukan pada tahun 2008 hingga tahun 2012. DSAK telah menerbitkan 40 PSAK per 1 Desember 2012. SAK 1 Januari 2012 sama dengan IFRS yang berlaku 1 Januari 2009. Sedangkan konvergensi IFRS fase ke-2 dimulai pada tahun 2014. Penerapan konvergensi tahap kedua mulai berlaku efektif pada 1 Januari 2015. SAK efektif 1 Januari 2015 sama dengan IFRS efektif 1 Januari 2014. Hal ini disampaikan oleh Rosita Uli Sinaga pada Workshop 2014 di Binus University.

Adopsi IFRS menuntut manajemen untuk mengungkapkan informasi akuntansi lebih rinci dan detail. Pengungkapan dalam laporan keuangan harus sejalan dengan informasi yang dipakai untuk pengambilan keputusan yang diambil oleh manajemen. Tingkat pengungkapan yang lebih rinci dan detail mendekati pengungkapan full disclosure akan mengurangi tingkat asimetri informasi akuntansi antara pengguna laporan keuangan dan manajer.

\section{Pengaruh Adopsi IFRS terhadap Persistensi Laba}


Pada tahun 2005, perusahaan yang tergabung dalam negara-negara anggota Uni Eropa yang mencatatkan sahamnya di Bursa Efek Uni Eropa disyaratkan untuk menyiapkan laporan keuangan konsolidasi sesuai dengan IFRS. Berdasarkan data IASB, sampai tahun 2008, terdapat 102 negara yang telah menerapkan IFRS dengan berbagai tingkat keharusan yang berbeda-beda. Indonesia sendiri telah mulai mengadopsi IFRS pada tahun 2008 hingga 2010 (Zamzami, 2011). Penerapan IFRS ini sendiri secara internasional dilakukan sebagai upaya untuk memperkuat arsitektur keuangan global dan mencari solusi jangka panjang terhadap kurangnya transparansi informasi keuangan.

Menurut Doukakis (2010), adopsi IFRS mungkin dapat meningkatkan persistensi laba di masa mendatang. Melalui IFRS, manajemen dapat menggunakan judgement yang diperbolehkan IFRS untuk meningkatkan kualitas laporan keuangan. Berdasarkan penelitian Pahlevi (2014) pada perusahaan perbankan di Indonesia, ditemukan bahwa kualitas laba setelah penerapan SAK adopsi IFRS lebih tinggi dibandingkan kualitas laba sebelum penerapan SAK IFRS. Penelitian Ahmed et al (2013) menyatakan bahwa hubungan antara laba dan nilai pasar ekuitas meningkat seiring dengan penerapan IFRS. Pengakuan, pengukuran, dan pengungkapan yang ada pada IFRS mampu memfasilitasi kemampuan analis keuangan untuk memprediksi laba di masa mendatang.

Pada penelitian Doukakis (2010) pada perusahaan non-finansial di Yunani menunjukkan bahwa IFRS tidak meningkatkan persistensi laba. Menurut penelitian Wardhani (2009), konvergensi GAAP lokal dengan IFRS tidak berpengaruh terhadap prediktabilitas laba di masa mendatang. IFRS yang berbasis prinsip mungkin menyebabkan adanya interpretasi dari perusahaan dalam memberikan penilaian secara subyektif saat menerapkan standar IFRS. Hal ini membuat laporan keuangan sulit untuk diprediksi. Berdasarkan uraian di atas, peneliti menyusun hipotesis sebagai berikut:

H1: Semakin konvergen laporan keuangan perusahaan terhadap IFRS, maka informasi laba yang disajikan makin persisten.

\section{Komponen Laba yang Persisten}

Laba dapat dibedakan menjadi laba operasi dan laba non-operasi. Menurut Febrianto (2005), laba operasi adalah selisih laba kotor dengan biaya operasi. Biaya operasi yang 
dimaksud adalah biaya yang sering terjadi di dalam perusahaan dan bersifat operatif. Termasuk juga biaya yang diasumsikan memiliki hubungan dengan penciptaan pendapatan.

Standar yang digunakan dalam pelaporan dan penyajian laporan keuangan akan mempengaruhi komponen dari laba bersih. Salah satu pengaruh standar yang digunakan adalah dalam hal pengakuan dan pengukuran pendapatan dan beban. Laba operasional yang informatif cenderung dapat menggambarkan laba bersih perusahaan di periode selanjutnya. Dengan adopsi IFRS seharusnya memungkinkan adanya penyajian dan pengungkapan yang lebih transparan mengenai pendapatan dan beban perusahaan sehingga laba operasi dinyatakan berkualitas. Kualitas laba operasi ini dapat mencerminkan kualitas laba bersih perusahaan. Menurut Doukakis (2010), laba operasi menunjukkan aktivitas operasional yang memberikan kontribusi utama dalam pembentukan laba bersih atau net income. Sedangkan laba non-operasional ditentukan oleh subyektifitas yang tinggi dibanding laba operasional. Hevas dalam Doukakis (2010) menyatakan bahwa pendapatan dari sekuritas bersifat sementara dan umumnya digunakan oleh manajemen perusahaan sebagai alat untuk mengatur laba bersih. Konvergensi IFRS mungkin dapat berdampak pada persistensi komponen laba dalam memprediksi laba bersih di masa mendatang. Berdasarkan uraian di atas, peneliti menyusun hipotesis sebagai berikut:

H2: Operating Income lebih dapat memprediksi Net Income di periode mendatang dibandingkan dengan Non-Operating Income pada saat laporan keuangan semakin konvergen terhadap IFRS.

\section{METODE}

Penelitian ini menggunakan pendekatan kuantitatif dengan sampel berupa perusahaan dalam semua sektor industri yang terdaftar di Bursa Efek Indonesia dengan syarat tertentu mulai dari tahun 2012 hingga 2015. Pemilihan tahun didasarkan pada konvergensi IFRS secara bertahap di Indonesia dimulai pada tahun 2012 dan tahun 2015 dipilih untuk bisa melihat secara gradual/bertahap bagaimana semakin konvergen IFRS mempengaruhi persistensi dari perusahaan go public di BEI.

Pemilihan sampel menggunakan teknik purposive sampling atau judgemental sampling dengan kriteria yang telah ditentukan sendiri oleh peneliti. Total sampel selama 4 tahun sebelum dilakukan pembatasan sebanyak 2.140 data. Pembatasan yang dilakukan 
adalah perusahaan sebagai sampel harus terdaftar di Bursa Efek Indonesia dan mengeluarkan laporan keuangan mulai dari tahun 2012 hingga 2015 secara lengkap. Pembatasan kedua, dari perusahaan yang sudah melewati pembatasan pertama, disaring lagi perusahaan yang menggunakan mata uang Rupiah. Sedangkan pembatasan ketiga adalah perusahaan yang nilai ekuitas tiap tahunnya tidak negatif. Dari pembatasan yang ada, terdapat 338 perusahaan yang akhirnya menjadi sampel, sehingga total data yang digunakan sejumlah 1.352 data.

\section{Variabel dan Definisi Operasional}

\section{Laba bersih}

Dalam penelitian ini, ROE digunakan sebagai alat untuk mengukur laba perusahaan. Hal ini bertujuan untuk menghilangkan pengaruh skala (scale effect) sehingga semua variabel dibagi dengan nilai tertentu. Pada penelitian ini, nilai tertentu yang digunakan adalah nilai buku ekuitas perusahaan pada akhir tahun sebelum tahun berjalan (t-1). Untuk selanjutnya, ROE disebut dengan Net Income untuk menghindari salah persepsi mengenai ROE sebagai pengukuran tingkat penngembalian suatu perusahaan.

$\mathrm{NI}_{\mathrm{t}}$ merupakan variabel independen atau variabel bebas sedangkan $\mathrm{NI}_{(\mathrm{t}+1)}$ merupakan variabel dependen atau variabel tergantung yang digunakan sebagai pengukuran untuk melihat seberapa persisten laba perusahaan dengan semakin konvergennya IFRS. Mengacu pada penelitian dari Doukakis (2010), perhitungan NI yang digunakan untuk penelitian ini adalah dengan menggunakan rumus:

$$
\mathrm{NI}=\frac{\text { NET INCOME }}{\text { BOOK VALUE OF EQUITY }}
$$

Net income yang digunakan dalam rumus tersebut didapat dari laporan keuangan. Sedangkan Book Value of Equity diperoleh dari laporan keuangan bagian laporan posisi keuangan pada akhir tahun sebelum tahun berjalan.

\section{Operating Income (OI)}

Operating income atau laba operasi merupakan laba yang diperoleh dari kegiatan operasional perusahaan sehari-hari. Laba operasi dapat dilihat pada laporan keuangan bagian laporan laba rugi komprehensif. Operating income didapat dari penjualan bersih dikurangi beban pokok penjualan (Cost of Goods Sold/COGS), beban umum dan administrasi serta penjualan, depresiasi, dan beban operasi lainnya atau dapat dirumuskan sebagai berikut. 


$$
\mathrm{OI}_{\mathrm{t}}=\text { Sales }_{\mathrm{t}}-\mathrm{COGS}_{\mathrm{t}}-\text { Selling, General and Administrative Expenses } \mathrm{t}_{\mathrm{t}}
$$

Operating income tahun berjalan merupakan variabel independen yang nantinya dibagi dengan book value equity tahun $\mathrm{t}-1$.

\section{Non-Operating Income (NOI)}

Non-operating income atau laba non-operasi merupakan laba yang diperoleh perusahaan selain daripada kegiatan operasional perusahaan sehari-hari. Laba non-operasi dapat juga dilihat pada laporan keuangan perusahan. Laba non-operasi didapat dari laba bersih (Net income) dikurangi laba operasi (Operating income/OI). Sehingga didapat rumusan sebagai berikut.

$$
\mathrm{NOI}_{\mathrm{t}}=\mathrm{NI}_{\mathrm{t}}-\mathrm{OI}_{\mathrm{t}}
$$

Non-operating income tahun t atau tahun berjalan merupakan variabel dependen yang dibagi dengan book value equity tahun t-1.

\section{Model Regresi}

$$
\begin{aligned}
& \mathrm{NI}_{\mathrm{t}+1}=\mathrm{a}+\mathrm{b} \mathrm{NI}_{\mathrm{t}}+\varepsilon_{\mathrm{t}+1} \ldots \ldots \ldots . . . \\
& \mathrm{NI}_{\mathrm{t}+1}=\mathrm{a}+\mathrm{b} \mathrm{OI}_{\mathrm{t}}+\mathrm{c} \mathrm{NOI}_{t}+\xi_{1}
\end{aligned}
$$

dimana:

$\mathrm{NI}_{\mathrm{t}+1}=$ Net Income tahun selanjutnya

$\mathrm{NI}_{\mathrm{t}}=$ Net Income tahun berjalan

$\mathrm{OI}_{\mathrm{t}}=$ Operating Income tahun berjalan

$\mathrm{NOI}_{\mathrm{t}}=$ Non-Operating Income tahun berjalan

Untuk kedua regresi akan dilakukan uji 4 asumsi klasik dan dilanjutkan dengan analisis regresi linier, berupa uji F, koefisien determinan $\left(\mathrm{R}^{2}\right)$, dan uji t. Hipotesis 1 terbukti jika nilai koefisien dari $\mathrm{NI}_{\mathrm{t}}$ dari tahun ke tahun semakin besar atau perbedaan nilai koefisien regresinya signifikan. Hipotesis 2 diterima bila koefisien $\mathrm{OI}_{t}$ lebih besar dari koefisien $\mathrm{NOI}_{t}$ dan selisih dari koefisien $\mathrm{OI}_{\mathrm{t}}$ dan $\mathrm{NOI}_{\mathrm{t}}$ semakin besar.

\section{HASIL}

\section{Statistik Deskriptif}

Statistik deskriptif menjelaskan mengenai gambaran karakteristik-karakteristik dari sampel penelitian yang mewakili populasinya. Karakteristik sampel yang dimaksud dalam 
penelitian ini meliputi jumlah sampel, nilai maksimum, dan nilai minimum untuk masingmasing variabel penelitian yang diukur dengan menggunakan data yang telah disaring sebelumnya. Statistik deskriptif penelitian ini dapat dilihat pada tabel berikut.

Tabel 1. Statistik Deskriptif untuk Regresi 1

\begin{tabular}{|c|c|c|c|}
\hline Keterangan & $\mathbf{N}$ & Minimum & Maximum \\
\hline $\mathrm{NI}_{\mathrm{t}}$ & 1.142 & $-1,310244466$ & 0,965312487 \\
\hline $\mathrm{NI}_{\mathrm{t}+1}$ & 1.142 & $-1,007392618$ & 0,812905364 \\
\hline
\end{tabular}

Tabel 2. Statistik Deskriptif untuk Regresi 2

\begin{tabular}{|c|c|c|c|}
\hline Keterangan & $\mathbf{N}$ & Minimum & Maximum \\
\hline $\mathrm{OI}_{\mathrm{t}}$ & 1.218 & $-0,940283581$ & 0,2153274588 \\
\hline $\mathrm{NOI}_{\mathrm{t}}$ & 1.218 & $-1,294397534$ & 0,736201145 \\
\hline $\mathrm{NI}_{\mathrm{t}+1}$ & 1.218 & $-0,481441402$ & 0,719255233 \\
\hline
\end{tabular}

\section{Uji Asumsi Klasik}

Pengujian hipotesis pada penelitian ini menggunakan permodelan linier berganda. Oleh sebab itu, sebelum melakukan uji hipotesis, perlu dilakukan terlebih dahulu uji asumsi klasik. Menurut Nugroho (2005), model regresi linier dapat dikatakan baik jika model tersebut dapat memenuhi uji asumsi klasik.

Pertama, uji normalitas bertujuan untuk memastikan apakah error (unstandardized residual) memiliki distribusi normal (Gujarati, 2003). Uji normalitas dilakukan dengan menggunakan metode One Sample Kolrnogorov Smirnov Test. Untuk regresi 1, jumlah sampel awal sebanyak 1352 sampel telah diuji, dan dinyatakan tidak normal karena nilai sig. kurang dari 0,05. Dengan menggunakan metode boxplot, peneliti melakukan pembuangan outlier atau data sebanyak 210 data atau 15,53\% dari data sampel awal sehingga data pada regresi 1 berdistribusi normal dengan nilai sig. sebesar 0,065. Pada regresi 2, sampel awal berjumlah 1.352 data dan juga dinyatakan bahwa data regresi 2 tidak berdistribusi normal. Peneliti melakukan pembuangan sebanyak 134 data atau 9,91\% dari sampel awal. Melalui 
pembuangan data tersebut, data pada regresi 2 berdistribusi normal dengan nilai Asimp Sig. sebesar 0,062 .

Kedua, uji heteroskedastisitas untuk melihat apakah terdapat ketidaksamaan varian dari residual untuk semua pengamatan pada model regresi. Variabel independen untuk regresi 1 dan 2 memiliki nilai sig. dibawah 0,05. Ini berarti variabel independen regresi 1 dan regresi 2 memiliki masalah heteroskedastisitas. Walaupun begitu, variabel independen untuk regresi 1 dan regresi 2 tetap akan dipakai mengingat pada regresi 1 hanya ada 1 variabel independen dan pada regresi 2 hanya ada 2 variabel independen. Menurut Gujarati (2003), masalah heteroskedastisitas tidak akan merusak konsistensi dan unbiasedness dari data yang digunakan penelitian.

Ketiga, uji autokorelasi menggunakan metode durbin-watson. Untuk model regresi 1, $\mathrm{NI}_{\mathrm{t}}$, nilai Durbin Watson (DW) sebesar 1,974 diantara dU dan 4-dU. Model regresi 2, $\mathrm{OI}_{\mathrm{t}^{-}}$ $\mathrm{NOI}_{\mathrm{t}}$, nilai Durbin Watson (DW) sebesar 1,943, juga diantara dU dan 4-dU. Dari hasil pengujian, regresi 1 dan 2 telah terbebas dari autokorelasi.

Keempat, uji multikolinieritas bertujuan untuk mengetahui apakah variabel independen memiliki korelasi satu dengan yang lain atau untuk menguji apakah terdapat lebih dari satu hubungan linear yang sempurna (Supranto, 1995). Model regresi 1 dengan variabel independen $\mathrm{NI}_{\mathrm{t}}$ dan model regresi 2 dengan variabel independen $\mathrm{OI}_{\mathrm{t}}$ dan $\mathrm{NOI}_{\mathrm{t}}$ memiliki nilai VIF kurang dari 10 dan nilai tolerance melebihi 10\% atau 0,1 sehingga model regresi 1 dan 2 juga terbebas dari multikolinieritas.

\section{Pengujian Hipotesis}

\section{Analisis Regresi Linier}

\section{Model Regresi 1}

Hipotesis pertama terdiri dari 1 variabel independen, yaitu $\mathrm{NI}_{\mathrm{t}}$ dan 1 variabel dependen $\mathrm{NI}_{\mathrm{t}+1}$. Dari hasil pengujian, maka persamaan model regresi 1 dapat dinyatakan sebagai berikut.

$$
N I_{\mathrm{t}+1}=12.665 .653,54+0,703 N I_{\mathrm{t}}+\xi_{1}
$$

Konstanta pada persamaan tersebut menunjukkan nilai $\mathrm{NI}_{t+1}$ sebagai variabel dependen apabila nilai $\mathrm{NI}_{\mathrm{t}}$ sebesar 0 . Tanda positif di depan nilai koefisien $\mathrm{NI}_{\mathrm{t}}$ menunjukkan 
hubungan yang searah dengan $\mathrm{NI}_{\mathrm{t}+1}$. Apabila nilai $\mathrm{NI}_{\mathrm{t}}$ mengalami kenaikan 1 , maka nilai $\mathrm{NI}_{\mathrm{t}+1}$ akan naik sebesar 0,836 dan sebaliknya.

Model Regresi 2

Hipotesis kedua terdiri dari 2 variabel independen, yaitu $\mathrm{OI}_{\mathrm{t}}$ dan $\mathrm{NOI}_{\mathrm{t}}$ dengan 1 variabel dependen, $\mathrm{NI}_{\mathrm{t}+1}$. Dari hasil pengujian, maka persamaan model regresi 2 dapat dinyatakan sebagai berikut.

$$
N I_{\mathrm{t}+1}=20.486 .734,71+0,435 \mathrm{OI}_{\mathrm{t}}+0,344 \mathrm{NOI}_{t}+\xi_{1}
$$

Konstanta pada persamaan tersebut menunjukkan nilai $\mathrm{NI}_{t+1}$ sebagai variabel dependen apabila nilai $\mathrm{OI}_{\mathrm{t}}$ dan $\mathrm{NOI}_{\mathrm{t}}$ sebesar 0 . Tanda positif di depan nilai koefisien $\mathrm{OI}_{\mathrm{t}}$ dan $\mathrm{NOI}_{\mathrm{t}}$ menunjukkan hubungan yang searah dengan $\mathrm{NI}_{\mathrm{t}+1}$. Apabila $\mathrm{OI}_{t}$ dan $\mathrm{NOI}_{t}$ mengalami peningkatan maka $\mathrm{NI}_{\mathrm{t}+1}$ juga meningkat, begitu pula sebaliknya.

\section{Uji Simultan (Uji F)}

Uji simultan/Uji F bertujuan untuk mengetahui pengaruh dari variabel independen terhadap variabel dependen secara simultan (Gujarati, 2003). Berikut adalah hasil uji F untuk model regresi 1 dan 2

Tabel 3. Rangkuman Hasil Uji F untuk Model Regresi 1 dan 2

\begin{tabular}{|c|c|}
\hline Keterangan & Sig. \\
\hline Regresi 1 & 0,000 \\
\hline Regresi 2 & 0,000 \\
\hline
\end{tabular}

**Keterangan: nilai sig. $<0,05$

Tabel 4. Rangkuman Hasil Uji F untuk Model Regresi 1 dan 2 per Tahun

\begin{tabular}{|c|c|c|c|c|}
\hline \multirow{2}{*}{ Keterangan } & \multicolumn{4}{|c|}{ Sig. } \\
\cline { 2 - 5 } & $\mathbf{2 0 1 2}$ & $\mathbf{2 0 1 3}$ & $\mathbf{2 0 1 4}$ & $\mathbf{2 0 1 5}$ \\
\hline Regresi 1 & 0,000 & 0,000 & 0,000 & 0,000 \\
\hline Regresi 2 & 0,000 & 0,000 & 0,000 & 0,000 \\
\hline
\end{tabular}

Dari tabel 3, nilai sig. untuk regresi 1 dan regresi 2 sebesar 0,000 kurang dari 0,05. Hasil uji F per tahun untuk model regresi 1 dan regresi 2 pada tabel 4 juga memiliki nilai sig. sebesar 0,000. Hal ini berarti variabel independen untuk kedua regresi secara simultan 
berpengaruh pada variabel dependennya, baik secara keseluruhan dari 2012 hingga 2015 maupun per tahun.

\section{Analisis Koefisien Determinasi $\left(\boldsymbol{R}^{2}\right)$}

Koefisien determinasi diperlukan untuk mengetahui seberapa besar kemampuan variabel independen mampu menjelaskan perubahan yang terjadi pada variabel dependen (Gujarati, 2003). Berikut ini adalah rangkuman hasil koefisien determinasi untuk kedua model regresi.

Tabel 5. Rangkuman Hasil Analisis Koefisien Determinasi $\left(\mathbf{R}^{2}\right)$

\begin{tabular}{|c|c|}
\hline Keterangan & Adjusted R Square \\
\hline Regresi 1 & 0,699 \\
\hline Regresi 2 & 0,480 \\
\hline
\end{tabular}

Tabel 6. Rangkuman Hasil Analisis Koefisien Determinasi $\left(\mathbf{R}^{2}\right)$ per Tahun untuk Model Regresi 1 dan Regresi 2

\begin{tabular}{|c|c|c|}
\hline \multirow{2}{*}{ Tahun } & \multicolumn{2}{|c|}{ Adjusted R Square } \\
\cline { 2 - 3 } & Regresi 1 & Regresi 2 \\
\hline $\mathbf{2 0 1 2}$ & 0,681 & 0,432 \\
\hline $\mathbf{2 0 1 3}$ & 0,704 & 0,462 \\
\hline $\mathbf{2 0 1 4}$ & 0,660 & 0,475 \\
\hline $\mathbf{2 0 1 5}$ & 0,740 & 0,566 \\
\hline
\end{tabular}

Nilai koefisien determinasi untuk regresi 1 sebesar 0,699 atau 69,9\%. Hal ini berarti, variabel independen, $\mathrm{NI}_{t}$, dapat menjelaskan 69,9\% dari variabel dependen, $\mathrm{NI}_{\mathrm{t}+1}$. Sedangkan 30,1\% variabel dependen dijelaskan oleh variabel lain di luar model. Bila dilihat per tahun, nilai koefisien determinasi dari tahun 2012 hingga tahun 2015 berfluktuasi yang dapat dilihat pada tabel 6.

Nilai koefisien determinasi untuk regresi 2 sebesar 0,480 atau 48\%. Hal ini berarti variabel independen, $\mathrm{OI}_{\mathrm{t}}$ dan $\mathrm{NOI}_{\mathrm{t}}$ dapat menjelaskan $48 \%$ dari variabel dependen, $\mathrm{NI}_{\mathrm{t}+1}$. Sedangkan 52\% sisanya dijelaskan oleh variabel lain di luar model. Dapat dilihat pada tabel 
6, nilai koefisien determinasi dari tahun 2012 sampai tahun 2015 secara berturut-turut, 43,2\% ; 46,2\% ; 47,5\% ; 56,6\%. Koefisien determinasi dari tahun ke tahun untuk model regresi 2 mengalami peningkatan kehandalan sebesar 3\% dari tahun 2012 ke 2013, 1,3\% dari tahun 2013 ke 2014 dan 9,1\% dari tahun 2014 ke 2015.

\section{Uji Parsial (Uji t)}

Uji parsial/uji t bertujuan untuk mengetahui bagaimana pengaruh dari setiap variabel independen terhadap variabel dependen secara parsial. Berikut adalah hasil pengujian regresi linier untuk kedua model regresi.

Tabel 7. Rangkuman Hasil Uji t-test Model Regresi 1

\begin{tabular}{|c|c|c|c|}
\hline Variabel & B & t & Sig. \\
\hline Konstanta & 126655653,54 & 5,100 & 0,000 \\
\hline $\mathrm{NI}_{\mathrm{t}}$ & 0,703 & 51,524 & 0,000 \\
\hline
\end{tabular}

Tabel 8. Rangkuman Hasil Uji t-test Model Regresi 1 per tahun

\begin{tabular}{|c|c|c|c|}
\hline Variabel NI & $\mathbf{B}$ & $\mathbf{t}$ & Sig. \\
\hline 2012 & 0,720 & 24,417 & 0,000 \\
\hline 2013 & 0,702 & 26,307 & 0,000 \\
\hline 2014 & 0,747 & 23,333 & 0,000 \\
\hline 2015 & 0,689 & 28,663 & 0,000 \\
\hline
\end{tabular}

Berdasarkan tabel 7, dapat diketahui bahwa variabel $\mathrm{NI}_{\mathrm{t}}$ memiliki nilai sig. 0,000 dan nilai koefisien regresi positif. Hal ini berarti $\mathrm{NI}_{\mathrm{t}}$ memiliki pengaruh signifikan (sig. < $0,05)$ yang positif terhadap variabel $\mathrm{NI}_{\mathrm{t}+1}$. Pada tabel 8 juga telah dijabarkan hasil uji t-test per tahun mulai dari tahun 2012 hingga tahun 2015. Hasilnya menunjukkan bahwa $\mathrm{NI}_{\mathrm{t}}$ memiliki pengaruh yang signifikan karena nilai sig. nya sebesar 0,000 kurang dari 0,05. Dengan kata lain, peningkatan $\mathrm{NI}_{\mathrm{t}}$ akan meningkatkan nilai $\mathrm{NI}_{\mathrm{t}+1}$.

Tabel 9. Rangkuman Hasil Uji t-test Model Regresi 2

\begin{tabular}{|c|c|c|c|}
\hline Variabel & B & t & Sig. \\
\hline Konstanta & 20486734,71 & 6,156 & 0,000 \\
\hline $\mathrm{OI}_{\mathrm{t}}$ & 0,435 & 33,230 & 0,000 \\
\hline $\mathrm{NOI}_{\mathrm{t}}$ & 0,344 & 15,815 & 0,000 \\
\hline
\end{tabular}


Tabel 10. Rangkuman Hasil Uji t-test Model Regresi 2 per Tahun

\begin{tabular}{|c|c|c|c|}
\hline Variabel $\mathrm{OI}_{\mathrm{t}}$ & B & $\mathbf{T}$ & Sig. \\
\hline 2012 & 0,373 & 15,132 & 0,000 \\
\hline 2013 & 0,430 & 16,104 & 0,000 \\
\hline 2014 & 0,497 & 16,606 & 0,000 \\
\hline 2015 & 0,484 & 19,426 & 0,000 \\
\hline Variabel NOI $_{t}$ & B & $\mathbf{T}$ & Sig. \\
\hline 2012 & 0,350 & 7,078 & 0,000 \\
\hline 2013 & 0,291 & 7,149 & 0,000 \\
\hline 2014 & 0,354 & 6,745 & 0,000 \\
\hline 2015 & 0,406 & 11,536 & 0,000 \\
\hline
\end{tabular}

Berdasarkan tabel 9, dapat diketahui bahwa variabel $\mathrm{OI}_{\mathrm{t}}$ dan $\mathrm{NOI}_{\mathrm{t}}$ memiliki nilai sig. 0,000 kurang dari 0,05 dengan nilai koefisien regresi positif. Hal ini menunjukkan variabel $\mathrm{OI}_{t}$ dan $\mathrm{NOI}_{t}$ berpengaruh signifikan yang positif terhadap variabel $\mathrm{NI}_{\mathrm{t}+1}$. Hal ini juga didukung dengan hasil pada tabel 10 yang menunjukkan uji t dari tahun 2012 hingga tahun 2015. Nilai sig. dari tahun 2012 hingga 2015 sebesar 0,000 kurang dari 0,05. Peningkatan $\mathrm{OI}_{t}$ dan $\mathrm{NOI}_{t}$ akan meningkatkan nilai $\mathrm{NI}_{t+1}$.

\section{Pengujian Tambahan}

Peneliti melakukan pengujian regresi kembali dengan menambahkan variabel dummy dan variabel moderasi tahun sebagai variabel independen. Sehingga terdapat tambahan pada regresi yang sudah ada, yaitu:

$$
\begin{aligned}
& N I_{\mathrm{t}+1}=\mathrm{a}+\mathrm{b} N I_{\mathrm{t}}+\mathrm{d}_{2012}+\mathrm{d}_{2013}+\mathrm{d}_{2014}+\mathrm{d}_{2015}+\mathrm{d}_{2012} N I_{\mathrm{t}}+\mathrm{d}_{2013} N I_{\mathrm{t}}+\mathrm{d}_{2014} N I_{\mathrm{t}}+ \\
& \mathrm{d}_{2015} N I_{\mathrm{t}} \\
& N I_{\mathrm{t}+1}=\mathrm{a}+\mathrm{b} \mathrm{OI}+\mathrm{c} \mathrm{NOI}_{\mathrm{t}}+\mathrm{d}_{2012}+\mathrm{d}_{2013}+\mathrm{d}_{2014}+\mathrm{d}_{2015}+\mathrm{d}_{2012} \mathrm{OI}_{\mathrm{t}}+\mathrm{d}_{2013} \mathrm{OI}_{\mathrm{t}}+\mathrm{d}_{2014} \mathrm{OI}_{\mathrm{t}} \\
& +\mathrm{d}_{2015} \mathrm{OI}_{\mathrm{t}}+\mathrm{d}_{2012} \mathrm{NOI}_{t}+\mathrm{d}_{2013} \mathrm{NOI}_{t}+\mathrm{d}_{2014} \mathrm{NOI}_{t}+\mathrm{d}_{2015} \mathrm{NOI}_{t}
\end{aligned}
$$

Keterangan: $\mathrm{d}_{2012}=$ variabel dummy tahun 2012, dan seterusnya

$\mathrm{d}_{2012} N I_{\mathrm{t}}=$ variabel moderasi, yaitu variabel dummy tahun 2012 dikali dengan variabel $N I_{\mathrm{t}}$

Dan berikut adalah hasil uji t untuk regresi pertama 
Tabel 11. Rangkuman Hasil Uji t-test Model Regresi 1 dengan Variabel Moderasi dan Dummy

\begin{tabular}{|c|c|c|c|}
\hline $\begin{array}{c}\text { Variabel Moderasi } \\
\text { Tahun }\end{array}$ & B & t & Sig. \\
\hline 2012 & 0,720 & 25,519 & 0,000 \\
\hline 2013 & 0,702 & 26,704 & 0,000 \\
\hline 2014 & 0,747 & 22,108 & 0,000 \\
\hline 2015 & 0,689 & 28,365 & 0,000 \\
\hline
\end{tabular}

Dari tabel 11 dapat dilihat bahwa perbedaan koefisien regresi dari net income antar tahun, yaitu tahun 2012 dibanding tahun 2013, tahun 2013 dibanding 2014 dan tahun 2014 dibanding tahun 2015 memiliki nilai yang signifikan kurang dari 0,05. Sedangkan untuk hasil regresi ke-2 adalah sebagai berikut.

Tabel 12. Rangkuman Hasil Uji t-test Model Regresi 2 dengan Variabel Moderasi dan Dummy

\begin{tabular}{|c|c|c|c|}
\hline $\begin{array}{c}\text { Variabel Moderasi } \\
\text { Tahun }\end{array}$ & B & t & Sig. \\
\hline OI 2013 & 0,055 & 1,604 & 0,109 \\
\hline OI 2014 & 0,124 & 3,208 & 0,001 \\
\hline OI 2015 & 0,111 & 3,116 & 0,002 \\
\hline NOI 2012 & 0,350 & 7,660 & 0,000 \\
\hline NOI 2013 & 0,289 & 7,345 & 0,000 \\
\hline NOI 2014 & 0,354 & 6,479 & 0,000 \\
\hline NOI 2015 & 0,406 & 10,546 & 0,000 \\
\hline
\end{tabular}

Untuk regresi ke-2, perbedaan nilai koefisien regresi OI tahun 2013 dibanding tahun 2014, tahun 2014 dibanding tahun 2015 memiliki nilai yang signifikan di bawah 0,05. Sedangkan perbedaan nilai koefisien regresi OI tahun 2012 dibanding tahun 2013 tidak signifikan, sebesar 0,109. Dan pada hasil pengujian, tahun 2012 dikeluarkan dan berada dalam tabel excluded variables. Untuk perbedaan nilai koefisien regresi NOI tahun 2012 dibanding tahun 2013, tahun 2013 dibanding tahun 2014 dan tahun 2014 dibanding 2015 memiliki nilai signifikan di bawah 0,05. Sehingga perbedaannya signifikan. 


\section{PEMBAHASAN}

Berdasarkan uji t per tahun, nilai koefisien regresi $\mathrm{NI}_{\mathrm{t}}$ dari tahun 2012 hingga tahun 2015 cenderung fluktuatif. Namun, dari pengujian tambahan yang dilakukan dinyatakan bahwa perbedaan nilai koefisien regresi dari tahun 2012 hingga tahun 2015 nilainya signifikan. Hal ini berarti koefisien regresi $\mathrm{NI}_{\mathrm{t}}$ tidak semakin besar tetapi beda koefisiennya signifikan, sehingga hipotesis 1 yang menyatakan bahwa, "Semakin konvergen laporan keuangan perusahaan terhadap IFRS, maka informasi laba yang disajikan makin persisten” diterima.

Hasil penelitian sejalan dengan penelitian dari Pahlevi (2014) yang menyatakan bahwa dengan penerapan IFRS di Indonesia, laba perusahaan perbankan setelah penerapan IFRS semakin persisten dibanding dengan sebelumnya. Penelitian Darmawan (2013) pada perusahaan yang ada di Inggris dan Jerman juga membuktikan bahwa adopsi IFRS dapat meningkatkan kualitas informasi akuntansi dan direspon secara positif oleh para investor. Ahmed et al (2013) menyatakan bahwa hubungan antara laba dengan nilai pasar ekuitas meningkat seiring dengan penerapan IFRS. Kebijakan yang ada pada IFRS terkait dengan pengakuan, pengungkapan, dan pengukuran mampu memfasilitasi analis keuangan untuk memprediksi laba di masa mendatang. Hal ini dikarenakan IFRS menghendaki adanya transparansi atas penyajian dan pengungkapan laporan keuangan.

Untuk hipotesis kedua, secara keseluruhan selama tahun 2012-2015, nilai koefisien regresi $\mathrm{OI}_{\mathrm{t}}$ lebih besar dari $\mathrm{NOI}_{\mathrm{t}}$. Dilihat dari tahun ke tahun mulai tahun 2012 hingga tahun 2015, nilai koefisien regresi $\mathrm{OI}_{\mathrm{t}}$ pada tabel 10 selalu lebih besar dari nilai koefisien regresi $\mathrm{NOI}_{\mathrm{t}}$. Meskipun pada tahun 2015 nilai koefisien $\mathrm{OI}_{\mathrm{t}}$ menurun, namun nilainya tetap lebih besar dari $\mathrm{NOI}_{t}$. Selisih dari koefisien regresi $\mathrm{OI}_{\mathrm{t}}$ dan $\mathrm{NOI}_{\mathrm{t}}$ juga meningkat dari tahun ke tahun, kecuali pada tahun 2015. Dari pengujian tambahan juga dapat dilihat bahwa nilai koefisien regresi OI dan NOI dari tahun ke tahun signifikan, kecuali pada perbandingan tahun 2012 dan 2013. Hal ini membuktikan bahwa operating income lebih dapat memprediksi net income di masa mendatang dibanding dengan non-operating income. Sehingga H2 untuk penelitian ini diterima walaupun pada tahun 2015, selisih dari $\mathrm{OI}_{t}$ dan $\mathrm{NOI}_{\mathrm{t}}$ menurun dibanding tahun sebelumnya. 
Doukakis (2010) dalam penelitiannya menyatakan bahwa operating income merupakan indikator yang baik untuk memprediksi profitabilitas di masa mendatang. Sedangkan non-operating income tidak cukup informatif untuk memprediksi net income di masa mendatang. Operating income dan non-operating income sama-sama memiliki kemampuan untuk memprediksi net income di masa yang akan datang. Hanya saja, operating income lebih mampu memprediksi karena memiliki kandungan informasi yang lebih baik untuk net income masa mendatang dibandingkan dengan non-operating income.

\section{KESIMPULAN}

Hasil penelitian ini menunjukkan bahwa semakin konvergen IFRS di Indonesia, net income semakin persisten untuk memprediksi net income di masa mendatang. IFRS yang menekankan pada transparansi laporan keuangan dalam hal pengungkapan, pengukuran dan penyajian laporan keuangan menyebabkan laba yang dihasilkan semakin persisten. Sesuai dengan penelitian dari Pahlevi (2014) yang menyatakan bahwa dengan adopsi IFRS, laba perusahaan menjadi persisten.

Dari hasil uji t per tahun, operating income lebih mampu untuk memprediksi laba di masa mendatang dibanding non-operating income. Non-operating income memiliki kandungan informasi yang tidak sistematis, mengingat praktik pelaporan, pengungkapan, serta sifat peristiwa pada non-operating income yang tidak berulang. Sedangkan operating income memiliki kandungan informasi yang lebih sistematis untuk memprediksi laba di masa mendatang. Penurunan koefisien regresi $\mathrm{OI}_{t}$ tahun 2015 mungkin disebabkan adanya fase kedua konvergensi IFRS yang berlaku secara efektif pada 1 Januari 2015. Hal ini membuat badan usaha harus melakukan penyesuaian atas penyusunan laporan keuangan. Sehingga, koefisien regresi $\mathrm{OI}_{\mathrm{t}}$ mengalami penurunan namun masih lebih tinggi nilainya dibanding $\mathrm{NOI}_{\mathrm{t}}$.

Dalam proses pengerjaan dan penyelesaian skripsi ini, peneliti mempunyai beberapa keterbatasan. Hal ini dapat menyebabkan perbedaan hasil dengan penelitian-penelitian sebelumnya. Keterbatasan tersebut berupa sampel yang digunakan hanya 63,17\% data perusahaan dari total populasi yang diambil sehingga mungkin tidak dapat sepenuhnya mencerminkan populasi badan usaha yang ada di Bursa Efek Indonesia. Kedua, variabel yang digunakan untuk regresi 1 hanya 1 variabel independen dan 1 variabel dependen, sedangkan 
untuk regresi 2 hanya 2 variabel independen dan 1 variabel dependen serta variabel independen pada regresi 1 dan regresi 2 tidak lolos pada uji heteroskedastisitas. Untuk keterbatasan tersebut, penelitian berikutnya bisa memperpanjang periode yang diteliti serta menambah variabel kontrol.

Penelitian ini diharapkan dapat menjadi acuan dan memberi tambahan pengetahuan bagi penelitian berikutnya dengan topik yang sejenis. Hasil penelitian dapat menunjukkan kepada investor dan badan usaha bahwa prediksi laba di masa mendatang dapat dilihat dari net income dan komponennya terutama operating income.

\section{DAFTAR PUSTAKA}

Amir, E., Eti Einhorn dan Itay Kama. 2012. Extracting Sustainable Earnings from Profit Margin. Tel Aviv University, Israel.

Ahmed, Kamran., et al. 2013. A Meta-analysis of IFRS Adoption Effect. The International Journal of Accounting 48:173-217

Darmawan, Arif. 2013. Pengaruh Adopsi IFRS Terhadap Earnings Response Coefficient pada Perusahaan di Inggris dan Jerman. Jurnal Akuntansi, Ekonomi dan Manajemen Bisnis Vol 3 No 1: 46-54

Doukakis, Leonidas C. 2010. The Persistence of Earnings and Earnings Components After The Adoption of IFRS. Managerial Finance Vol 36: 969-981

Fama, Eugene F. dan Kenneth R. French. 2002. Testing Trade-Off and Pecking Order Predictions about Dividends and Debt. The Review of Financial Studies Vol 15 no. 1: 1-33

Gujarati, Damodar N. 2003. Basic Econometrics. McGraw Hill.

Handayaningsih, Lucky. 2015. Dampak Penerapan IFRS bagi Perusahaan dan bagi Dunia Pendidikan di Indonesia. Kompasiana. 13 Januari 2015 (http://www.kompasiana.com/lucky_handayaningsih/dampak-penerapan-ifrs-bagi-perusahaandan-bagi-dunia-pendidikan-di-indonesia_54f91132a33311af068b4589)

Horngren, Charles T., Foster, George dan Datar, Srikant M. 2015. Cost Accounting: A Managerial Emphasis $15^{\text {th }}$ edition. England: Pearson Education Limited

Pahlevi, M. Reza. 2014. Persistensi Laba Sesudah Adopsi Standar Akuntansi Internasional (IFRS) [Tesis]. Universitas Lampung, Lampung, Indonesia

Penman, Stephen H. 2003. The Quality of Financial Statements: Perspectives from The Recent Stock Market Bubble. Accounting Horizons: 77-96

Prastika, Nurhikma Esti, Yohani, Haifa Kurniawati. 2014. Analisis Komparasi Terhadap Kualitas Informasi Akuntansi Sebelum dan Sesudah Penerapan Standar Akuntansi Keuangan Internasional di Indonesia. Journal.stiemuhpkl.ac.id 
Schipper, K., dan Vincent, L. 2003. Earnings Quality. Accounting Horizons 17:97-110

Shobriati', Ikrima dan Siregar, Sylvia V.N.P. 2016. Pengarh Tingkat Adopsi IFRS dan Proteksi Investor terhadap Persistensi Laba: Analisis Linats Negara Emerging Market. Jurnal Manajemen Teknologi 15: 324-344

Sinaga, Rosita Uli. 2014. Ringkasan Worskshop PSAK Update. Binus University. (https://accounting.binus.ac.id/2014/09/01/status-konvergensi-ifrs-psak/)

Sunarto. 2008. Peran Persistensi Laba Memperlemah Hubungan Antara Earnings Opacity dengan Cost of Equity dan Trading Volume Activity [Disertasi]. Universitas Diponegoro, Semarang, Indonesia

Tucker, J.W. dan P.A. Zarowin. 2006. Does Income Smoothing Improve Earnings Informativeness?. The Accounting Review, Vol. 81 No. 1: 251-270

Wardhani, R. (2009). Pengaruh Proteksi Bagi Investor, Konvergensi Standar Akuntansi, Implementasi Corporate Governance, dan Kualitas Audit Terhadap Kualitas Laba: Analisis Lintas Negara di Asia. [Disertasi]. Universitas Indonesia, Depok, Indonesia. 